\title{
sciendo
}

\section{Studies on uranium recovery from a U-bearing Radoniów Dump}

\author{
Katarzyna Kiegiel $\mathbb{C}^{\text {, }}$ \\ Otton Roubinek $\mathbb{0}$, \\ Dorota Gajda (1), \\ Paweł Kalbarczyk 무, \\ Grażyna Zakrzewska-Kołtuniewicz (1), \\ Andrzej G. Chmielewski
}

\begin{abstract}
This work reports the possibility of uranium recovery from a post-mining uranium ore dump in Poland by a bioleaching method. The studies were conducted on the dump leaching model with the mass of $570 \mathrm{~kg}$ of uranium bearing mineral material from Radoniów pile and in the periodic bioreactor with a work volume of $80 \mathrm{dm}^{3}$ and with mechanical mixing and aeration of the charge. The uranium concentration in the examined material was about $800 \mathrm{ppm}$. In this process, the consortium of microorganisms isolated from former mines was used. It was composed of the following microorganisms: Bacillius, Pseudomonas, Sphingomonas, Thiobacillus, Halothiobacillus, Thiomonas, and Geothrix. The efficiency of the uranium bioleaching process was $98 \%$ in the reactor, and a yield of $70 \%$ was obtained in the dump leaching model. The post-leaching solution contained significant amounts of uranium ions that were separated in two stages: (1) by ion chromatography and then (2) by a two-step precipitation method. The resulting solution was a source of ammonium diuranate, the precursor of yellowcake (uranium oxides).
\end{abstract}

Keywords: Ammonium diuranate precipitation $\bullet$ Bioleaching $\bullet$ Uranium

K. Kiegiel ${ }^{\bowtie}$, D. Gajda, P. Kalbarczyk,

G. Zakrzewska-Kołtuniewicz, A. G. Chmielewski

Institute of Nuclear Chemistry and Technology

Dorodna 16 Str., 03-195 Warsaw, Poland

E-mail: k.kiegiel@ichtj.waw.pl

O. Roubinek

Institute of Nuclear Chemistry and Technology

Dorodna 16 Str., 03-195 Warsaw, Poland

and Warsaw University of Technology

Faculty of Chemistry

Laboratory of Technological Processes

Noakowskiego 3 Str., 00-664 Warsaw, Poland

Received: 22 December 2020

Accepted: 18 January 2021

\section{Introduction}

Nuclear energy continues to play an important role in today's energy sector, and according to all forecasts, it will remain a significant component of the energy mix in the future. This is connected with a need of decarbonization of the energy sector, which still needs development of a sustainable energy source. Nuclear power can fill the gap left after shutdown of power plants using fossil fuels such as lignite and hard coal. For this reason, the continuous development of nuclear energy leads to an inevitable increase in the demand for nuclear fuel and thus uranium. It is expected that future world demand for uranium will be covered by exploitation of secondary resources such as low-grade ore bodies and industrial wastes $[1,2]$. In addition to the well-developed methods that are already applied for uranium recovery $[3,4]$, bioleaching of uranium from raw materials and industrial waste containing uranium might be also a technically available solution [5-7]. Bioleaching is an economically advantageous process that is broadly used for the recovery of metals from various materials $[8,9]$. In this study, the post-mining uranium dump from Radoniów (Fig. 1) was considered as the potential

0029-5922 () 2021 The Author(s). Published by the Institute of Nuclear Chemistry and Technology.

This is an open access article under the CC BY-NC-ND 4.0 licence (http://creativecommons.org/licences/by-nc-nd/4.0/). 


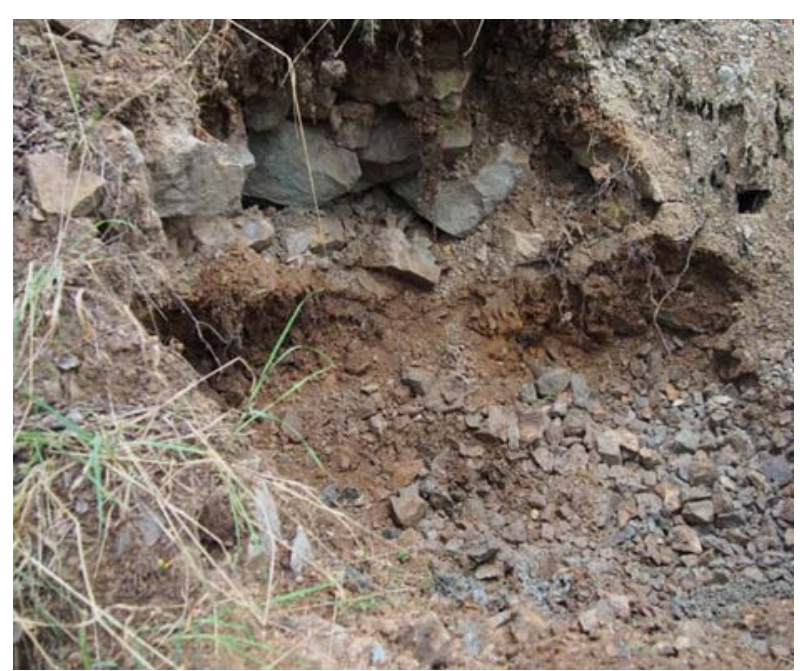

Fig. 1. The photo of a material sampling point at the post-mining uranium dump in Radoniów.

secondary resource of uranium. The Radoniów deposit is located in Western Sudetes (SW Poland). Uranium mining had been started in there in 1954 and continued until 1960.

One of the most important steps in $U$ fuel manufacturing is obtaining the yellowcake. The yellowcake can be precipitated from the solution over a wide $\mathrm{pH}$ range, either in acidic or alkaline media. It depends on the composition of the solution and precipitant. The precipitation of uranium salt from acidic solution is carried out by adding reagents such as aqueous ammonia, sodium hydroxide, magnesium oxide, or hydrogen peroxide $[10,11]$.

\section{Materials and methods}

Post-mining U-bearing dumps are located near the former Radoniów mine. Currently, two dumps exist there, the so-called Small Dump and Big Dump they differ in size and uranium content. The material investigated in this study originated from the Small Dump and the uranium concentration was about $747-800 \mathrm{ppm}$. The chemical analysis of two samples of the ore from that pile is presented in Table 1. About 1.5 tons of material were collected from the pile (in two portions) and then pre-fractionated.

The consortium of microorganisms isolated from former mines was used for bioleaching. It was composed of the following microorganisms: Bacillius, Pseudomonas, Sphingomonas, Thiobacillus, Halothiobacillus, Thiomonas, and Geothrix [7, 12]. The chemical composition of the bacteria medium is listed in Table 2.

All reagents were of analytical grade and were used as received without further purification. Dowex $1 \times 8$ resins were supplied by Dow Chemi-
Table 2. The composition of K0 bacteria medium used in the bioleaching process

\begin{tabular}{|c|c|}
\hline Component & Concentration $\left(\mathrm{g} / \mathrm{dm}^{3}\right)$ \\
\hline$\overline{\left(\mathrm{NH}_{4}\right)_{2} \mathrm{SO}_{4}}$ & 5 \\
\hline $\mathrm{KCl}$ & 0.166 \\
\hline $\mathrm{KH}_{2} \mathrm{PO}_{4}$ & 0.083 \\
\hline $\mathrm{MgSO}_{4} \cdot 7 \mathrm{H}_{2} \mathrm{O}$ & 0.830 \\
\hline $\mathrm{Ca}\left(\mathrm{NO}_{3}\right)_{3}$ & 0.024 \\
\hline \multicolumn{2}{|c|}{ pH 2} \\
\hline
\end{tabular}

cal Company. The total content of uranium in the post-bioleaching solution was determined by inductively couplet plasma mass spectrometry (ICP-MS) analysis [13].

\section{Results and discussion}

\section{Treatment of uranium ores}

The studies were carried out in the periodic bioreactor with agitation and aeration of the charge and in the model of dump leaching with the mass of $570 \mathrm{~kg}$ of uranium-bearing mineral material from Radoniów pile. The uranium concentration in the examined material was about 750-800 ppm (Table 1).

Bioleaching of uranium ores was carried out in the bioreactor developed at the Institute of Nuclear Chemistry and manufactured by Boccard Kates sp. $z$ o. o. from Olsztyn, Poland. The capacity of the bioreactor was $100 \mathrm{dm}^{3}$. The bioreactor was equipped with temperature and $\mathrm{pH}$ control systems, as well as with a mixing system with speed control and an aeration device. Figure 2 shows the scheme and photos of the reactor and the test stand.

In the experiment, about $98 \%$ of uranium was leached after 51 days of the process. The results are presented in Fig. 3.

In the second test, the experiment was scaled up, and bioleaching was carried out in the fixed-bed deposit to simulate in situ heap leaching process. The bed dimensions were $100 \mathrm{~cm} \times 120 \mathrm{~cm} \times$ $24 \mathrm{~cm}$. The deposit was placed in a pallet box as shown in Fig. 4. The pallet box was set up in such a way that it allowed free drainage of the liquid (slope at an angle of $2^{\circ}$ related to the outlet from the box). The construction of the bed deposit was as follows: a stainless steel mesh was placed in the box, and on top of it, a layer of pieces of ore with dimensions of more than $5 \mathrm{~cm}$ was placed. The height of this layer was $6-7 \mathrm{~cm}$. On top of this layer, the material with a grain size less than $5 \mathrm{~cm}$ was placed. The mass of charge was $570 \mathrm{~kg}$. Leaching was performed for 120 days. During the process, sulfuric acid was added to the solution to maintain the $\mathrm{pH}$ at $\sim 2$. The efficiency of uranium leaching reached $70 \%$.

Table 1. Chemical analysis of samples taken from the Small Dump in Radoniów

\begin{tabular}{ccccccccccccc}
\hline U & Th & $\mathrm{Cu}$ & $\mathrm{Co}$ & $\mathrm{Mn}$ & $\mathrm{Zn}$ & $\begin{array}{c}\mathrm{La} \\
(\mathrm{ppm})\end{array}$ & $\mathrm{V}$ & $\mathrm{Yb}$ & $\mathrm{Mo}$ & $\mathrm{Ni}$ & $\mathrm{Sb}$ & $\mathrm{Fe}$ \\
\hline 747 & 12 & 12 & 21 & 291 & 58 & 24 & 47 & 3 & 3 & 27 & 5 & 23200 \\
801 & 14 & 14 & 18 & 369 & 100 & 29 & 52 & 3 & 5 & 23 & 7 & 25200 \\
\hline
\end{tabular}


(a)

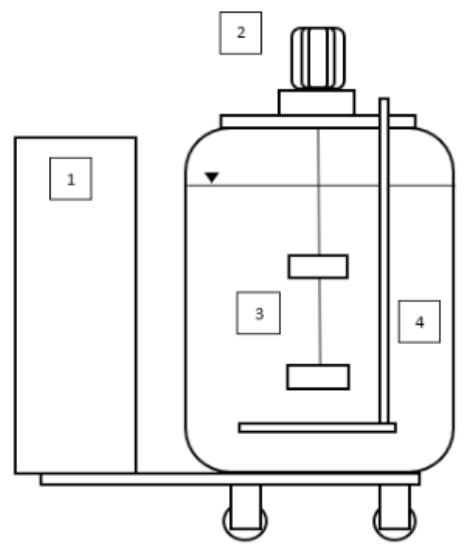

(b)

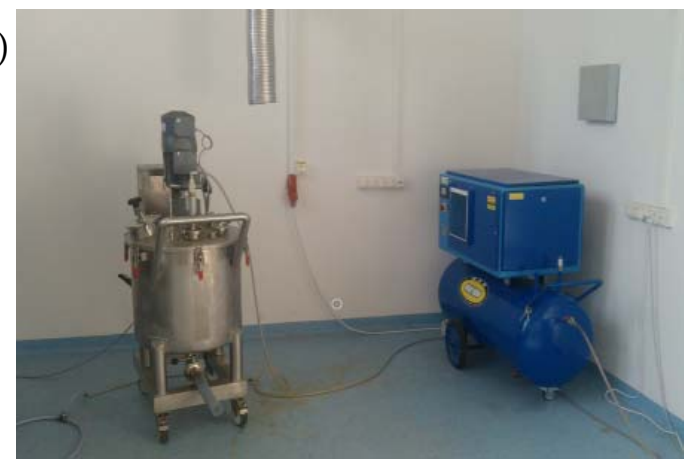

Fig. 2. (a) The scheme of the reactor: 1 - double-Rushton mixer, 2 - bubbler, 3 - control cabinet, and 4 - engine; (b) the reactor and control system panel built by Kates sp. z o. o.

Aeration was carried out by two disc diffusers in the lower tank. The solution was pumped into the spraying system located above the bed in the upper container. Liquid samples were collected at the inlet and outlet of the container. As shown in Fig. 5, the uranium concentration increased over time and reached a maximum after 120 days, and then, it started to decrease.

\section{lon-exchange chromatography}

After bioleaching uranium from the low U-content Radoniów ore, ion-exchange (IX) chromatography was used to separate uranium from other accompanying metals. The Dowex $1 \times 8$ (200-400 mesh) anion exchanger was chosen for this process. IX column parameters were as follows: $\mathrm{H}$ resin $=18.3 \mathrm{~cm}$,

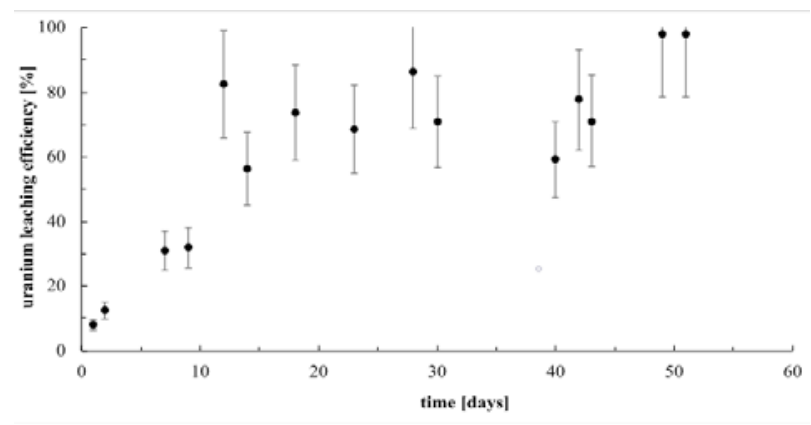

Fig. 3. The efficiency of uranium bioleaching in the reactor (initial uranium concentration in the rock: $750-800 \mathrm{ppm}$ ). (a)

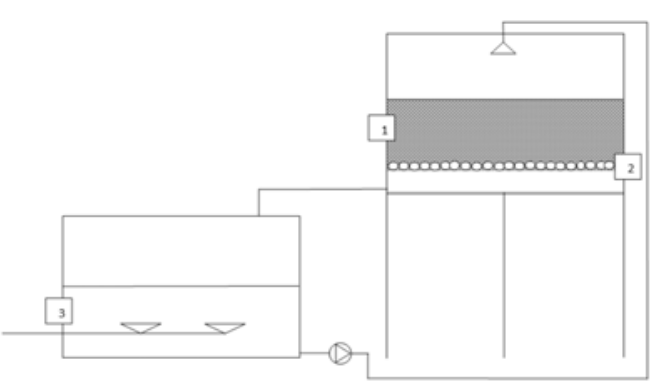

(b)

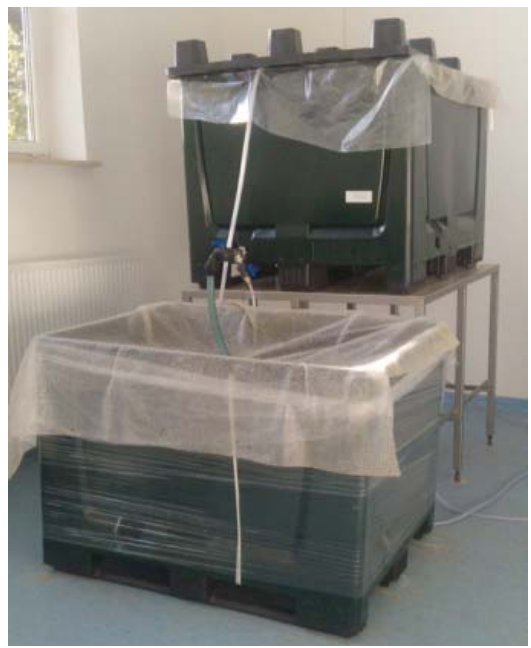

Fig. 4. Fixed-bed reactor. (a) The scheme of the experimental stand: 1 - leaching solution, 2 - U-bearing rocks from Radoniów pile, and 3 - post-leaching solution. (b) The experimental rig photo.

$\mathrm{D}=3.92 \mathrm{~cm}, \mathrm{~V}$ resin $=221 \mathrm{~cm}^{3}$, effluent flow $=$ $7.77 \mathrm{~cm}^{3} / \mathrm{min}$.

The post-bioleaching solution $\left(700 \mathrm{~cm}^{3}\right)$ was introduced into the IX column (Fig. 6). Subsequently, $3000 \mathrm{~cm}^{3}$ of $\mathrm{H}_{2} \mathrm{SO}_{4 \mathrm{aq}}(\mathrm{pH}=2)$ was used to rinse the accompanying metal ions, e.g., Fe, rare earth elements (REE), etc. They were collected in an accompanying metal container. Uranium ions, adsorbed on the resin bed, were eluted with $2 \mathrm{M}$ sulfuric acid, and this solution was collected into a "U solution container". In the first rinsing cycle of uranium, only fresh $2 \mathrm{M} \mathrm{H}_{2} \mathrm{SO}_{4}$ was used. Each subsequent aliquot of the eluting solution was composed of $2 \mathrm{M} \mathrm{H}_{2} \mathrm{SO}_{4}$ solution from the "U solution container" and fresh $2 \mathrm{M} \mathrm{H}_{2} \mathrm{SO}_{4}$, in the ratio of $900 \mathrm{~cm}^{3}: 300 \mathrm{~cm}^{3}$. At this stage, the uranium concentration was done (Table 3). The analysis of samples after I, X, XIV, and XVII cycles was also performed.

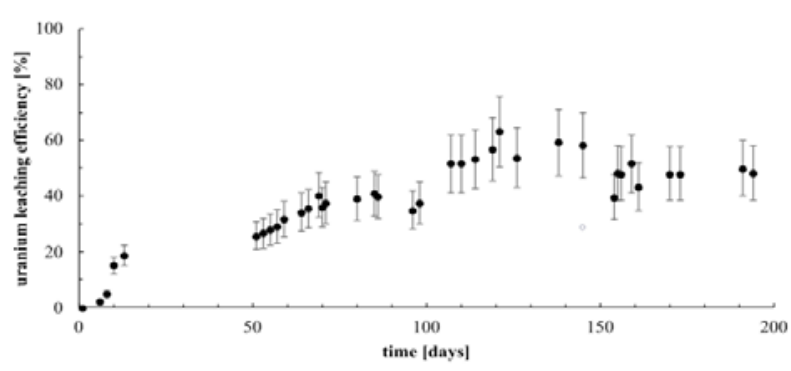

Fig. 5. The effect of time on uranium bioleaching in fixed-bed deposit (initial uranium concentration in the rock: $750-800 \mathrm{ppm}$ ). 


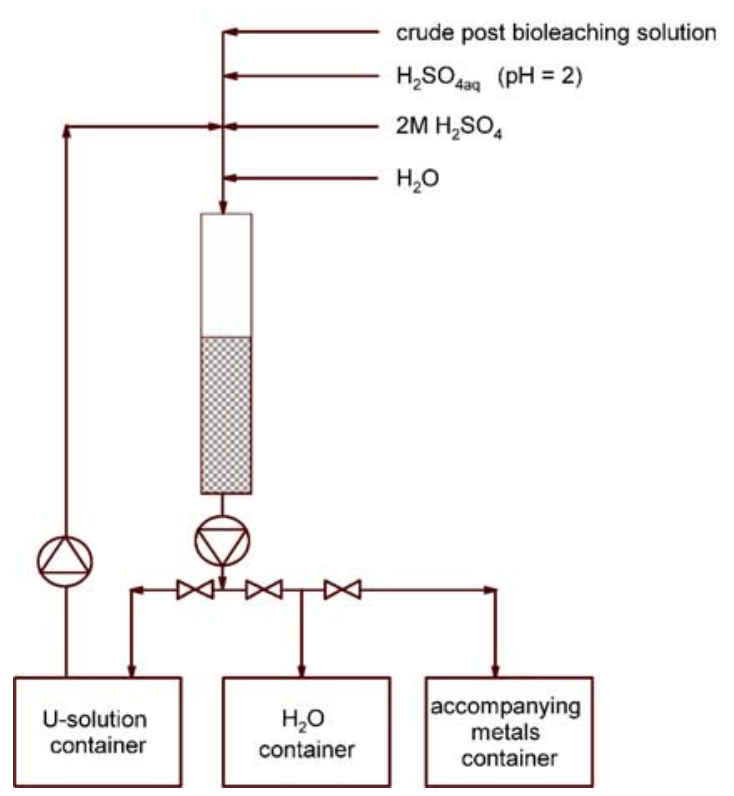

Fig. 6. The scheme of ion exchange process, used for the purification uranium post-bioleaching solution.

Table 3. The degree of uranium concentration by IX chromatography in the sample after bioleaching

\begin{tabular}{lccc}
\hline Sample & $\begin{array}{c}\text { Cycle } \\
\text { no. }\end{array}$ & $\begin{array}{c}\mathrm{U} \\
(\mathrm{ppm})\end{array}$ & $\begin{array}{c}\text { Uranium } \\
\text { concentration } \\
\text { degree }\end{array}$ \\
\hline $\mathrm{U}-1$ & $\mathrm{I}$ & 272 & - \\
$\mathrm{U}-2$ & $\mathrm{X}$ & 327 & 1.20 \\
$\mathrm{U}-3$ & $\mathrm{XIV}$ & 375 & 1.38 \\
$\mathrm{U}-4$ & XVIII & 413 & 1.52 \\
\hline
\end{tabular}

The U-4 samples from the XVIIIth cycle were used to precipitate the yellowcake.

In the process of uranium bioleaching, significant amounts of iron ions were co-leached. Unfortunately, these ions did not separate completely in the IX column. The U-4 solution after IX chromatography contained about $85 \mathrm{ppm}$ of iron, which impedes precipitation of uranium salts. For that reason, the pretreatment of the U-4 solution was needed before final precipitation of $U$ salts.

\section{Yellowcake precipitation}

The aim of the preliminary study was to select precipitating agents and reaction conditions appropriate for the recovery of uranium. Based on preliminary studies [14], the precipitation of uranium as ammonium diuranate was chosen. Ammonium diuranate can be easily transformed into uranium oxide $\left(\mathrm{U}_{3} \mathrm{O}_{8}\right)$ by calcination at $750^{\circ} \mathrm{C}$ for $4 \mathrm{~h}$. This method allows us to obtain a pure product from the solution with a low concentration of uranium. It was found that the efficiency of the model solution was $84-95 \%$ for the concentration ranging between $0.3 \mathrm{mg} / \mathrm{cm}^{3}$ and $2.4 \mathrm{mg} / \mathrm{cm}^{3}$.

The obtained solution contained iron ions, and for that reason, two-stage precipitation was adopted (Fig. 7).

Samples with a volume of $300 \mathrm{~cm}^{3}$ were used for the precipitation process. In the first step of precipitation, iron ions were removed from the solution using $25 \% \mathrm{NH}_{3 \mathrm{aq}}$. $\mathrm{U}$ solution (in $2 \mathrm{M} \mathrm{H}_{2} \mathrm{SO}_{4}$ ) was heated up to $60^{\circ} \mathrm{C}$ in a $600 \mathrm{~cm}^{3}$ beaker on the magnetic agitator with heating. After that, the ammonia solution was added dropwise to obtain a $\mathrm{pH}$ of 4-5. Subsequently, the whole mixture was agitated at $60^{\circ} \mathrm{C}$ for $1 \mathrm{~h}$. Then, the obtained suspension was filtered, without cooling it, with a sintered disc filter funnel (G5).

The filtered U solution was heated again up to $60^{\circ} \mathrm{C}$. After that, the ammonia solution was added after the first crystals formed $(\mathrm{pH} \mathrm{8-10)}$. The obtained mixture was heated for $4 \mathrm{~h}$ at $60^{\circ} \mathrm{C}$ and slowly agitated $(\sim 70-100 \mathrm{rpm})$. After that, the suspension was cooled over the night. On the next day, the solution was separated from precipitated U salts. The solid residue was dried at $60^{\circ} \mathrm{C}$ for $6-7 \mathrm{~h}$ and then at $105^{\circ} \mathrm{C}$ for $1 \mathrm{~h}$. After that, the solid residue was weighed, dissolved in $\mathrm{HNO}_{3}$, and subjected to ICP-MS analysis to identify the purity of the obtained solid phase. Ammonium diuranate with a yield of $60 \%$ was obtained, and iron separation from $U$ was carried out with a yield of 99\%.

\section{Conclusion}

The objective set by the circular economy policy requires that the recovery of metals from industrial waste should be considered in the context of environmental protection and saving natural resources.

Studies incumbently performed at the Institute of Nuclear Chemistry and Technology (INCT) have proven the possibility of bioleaching processes' application for metal extraction from post-mining uranium dumps. The obtained $70 \%$ efficiency

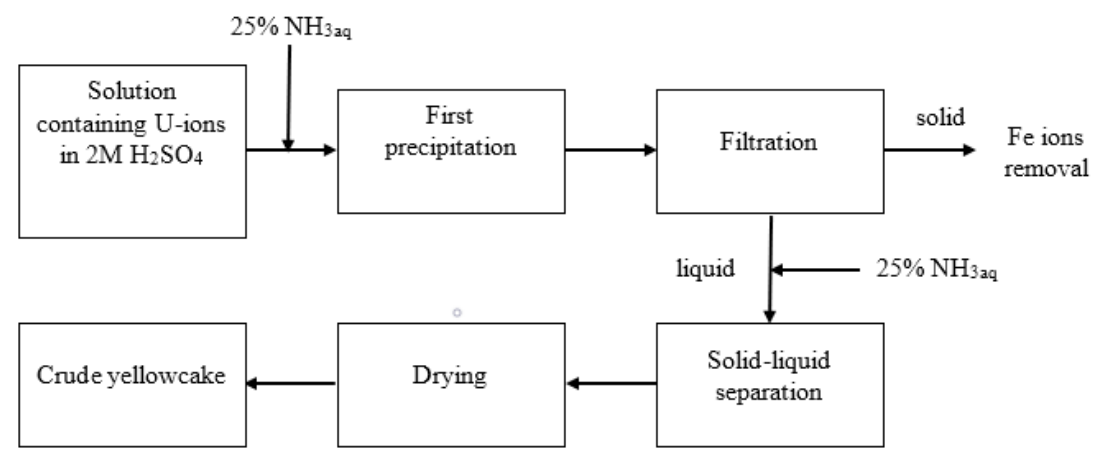

Fig. 7. Two-step precipitation of ammonium diuranate from prior purified post-bioleaching solution. 
of uranium bioleaching in fixed-bed deposit is a very promising result. Bioleaching efficiency and the process rate observed in a stirred reactor were higher; however, the energy consumption was rather high, which makes the process less economical. The outcomes of the study are developed analytical procedures and methods of dump leaching on a pilot scale, as well as a method of uranium separation from the solution obtained from bioleaching. The post-bioleaching solution contained significant amounts of iron ions that were separated in two stages: by IX chromatography and then by two-stage precipitation. The resulting solution was a source of ammonium diuranate, which is the precursor of uranium oxide purified from iron ions with an efficiency of $99 \%$. The yellowcake was precipitated with a yield of $60 \%$.

The obtained results are a collection of base guidelines for the preparation of technical assumptions for the design a bioleaching installation for the processing of 30 tons of charge on a dump. The resulting technology can be implemented to extract uranium from post-mining dumps in the future.

Acknowledgments. This work was supported by the NCBR Strategic Research Grant "Technologies supporting the development of safe nuclear energy (Research task no. 3: Basics for securing the fuel needs of the Polish nuclear energy, Stage 11: Research on bioleaching on a quarter technical scale)" and the Ministry of Science and Higher Education, Poland, financial resources for science in the years 2017-2019 granted for the implementation of the international project co-financed by IAEA Research contract no. 18542 . The authors acknowledge Professor A. Sklodowska (University of Warsaw), coordinator of the project, and her group for supplying microbial consortium.

\section{ORCID}

A. G. Chmielewski (I) http://orcid.org/0000-0001-6262-5952

D. Gajda (D http://orcid.org/0000-0002-6335-4792

P. Kalbarczyk (D) http://orcid.org/0000-0003-4264-3410

K. Kiegiel 10 http://orcid.org/0000-0003-2624-7303

O. Roubinek (1) http://orcid.org/0000-0002-6492-7118

G. Zakrzewska-Kottuniewicz (D) http://orcid.org/0000-00015201-1551

\section{References}

1. Kiegiel, K., Miskiewicz, A., Gajda, D., Sommer, S., Wolkowicz, S., \& Zakrzewska-Koltuniewicz, G. (2018). Uranium in Poland: Resources and recovery from low-grade ore. In S. Nasser \& S. Awwad (Eds.), Uranium (pp. 65-88). London: IntechOpen. DOI: 10.5772/intechopen.69413.

2. Kiegiel, K., Gajda, D., \& Zakrzewska-Kołtuniewicz, G. (2020). Recovery of uranium and other valuable metals from substrates and waste from copper and phosphate industries. Sep. Sci. Technol., 55(12), 2099-2107. DOI: 10.1080/01496395.2019.1642356.
3. Kiegiel, K., Zakrzewska-Kołtuniewicz, G., Gajda, D., Miśkiewicz, A., Abramowska, A., Biełuszka, P., Danko, B., Chajduk, E., \& Wołkowicz, S. (2015). Dictyonema black shale and Triassic sandstones as a potential sources of uranium. Nukleonika, 60(3), 515-522. DOI: 10.1515/nuka-2015-0096.

4. Miśkiewicz, A., Zakrzewska-Kołtuniewicz, G., Dłuska, E., \& Walo, P. F. (2016). Application of membrane contactor with helical flow for processing uranium ores. Hydrometallurgy, 163, 108-114. DOI: 10.1016/j.hydromet.2016.03.017.

5. Abhilash, \& Pandey, B. D. (2013) Microbially assisted leaching of uranium - a review. Mineral Process Extractive Metall. Rev., 34, 81-113. DOI: 10.1080/08827508.2011.635731.

6. Abhilash, \& Pandey, B. D. (2015). Microbial extraction of uranium from ores. In Abhilash, B. D. Pandey \& K. A. Natarajan (Eds.), Microbiology for minerals, metals, materials and the environment (pp. 59-98). London, UK: CRC Press, Taylor \& Francis Group. DOI: $10.1201 / \mathrm{b} 18124-4$.

7. Szolucha, M. M., \& Chmielewski, A. G. (2017). A comparison of uranium recovery from low-grade ore by bioleaching and acid leaching. Physicochem. Probl. Miner. Process., 53(1), 136-149. DOI: 10.5277/ ppmp170111.

8. Lee, J. -Ch., \& Pandey, B. D. (2012). Bio-processing of solid wastes and secondary resources for metal extraction - A review. Waste Manag., 32(1), 3-18. DOI: 10.1016/j.wasman.2011.08.010.

9. Potysz, A., Van Hullebusch, E. D., \& Kierczak, J. (2018). Perspectives regarding the use of metallurgical slags as secondary metal resources - A review of bioleaching approaches. J. Environ. Manag., 219, 138-152. DOI: 10.1016/j.jenvman.2018.04.083.

10. Gupta, R., Pandey, V. M., Pranesh, S. R., \& Chakravarty, A. B. (2004). Study of an improve technique for precipitation of uranium from elute solution. Hydrometallurgy, 71(3/4), 429-434. DOI: 10.1016/ S0304-386X(03)00116-6.

11. Kiegiel, K., Abramowska,A., Gajda, D., \& Zakrzewska-Kołtuniewicz, G. (2015). The study of precipitation of yellow cake for production of nuclear fuel. In Annual Report 2014 (pp. 36-37). Warsaw: Institute of Nuclear Chemistry and Technology,

12. Rewerski, B., Mielnicki, S., Bartosiewicz, I., Polkowska-Motrenko, H., \& Sklodowska, A. (2013). Uranium post-mining wastes as a potential reserve source of uranium for nuclear energy plants. Physicochem. Probl. Miner. Process., 49(1), 5-11. DOI: 10.5277/ppmp130101.

13. Chajduk, E., Bartosiewicz, I., Pyszynska, M., Chwastowska, J., \& Polkowska-Motrenko, H. (2013). Determination of uranium and selected elements in Polish dictyonema shales and sandstones by ICP-MS. J. Radioanal. Nucl. Chem., 295, 1913-1919. DOI: 10.1007/s10967-012-2330-9.

14. Kiegiel, K., Abramowska, A., Gajda, D., \& Zakrzewska-Kołtuniewicz, G. (2015). The study of precipitation of yellow cake for production of nuclear fuel. In Annual Report 2014 (pp. 36-37). Warsaw: Institute of Nuclear Chemistry and Technology. 